\title{
Alterations in protein synthetic capability of nerve cells in Alzheimer's disease
}

\author{
D M A MANN, D NEARY, P O YATES, J LINCOLN, \\ J S S NOW DEN, AND P T A N WORTH \\ From the Departments of Neuropathology, Neurology and Neurosurgery, University of Manchester
}

SUMMARY Cytoplasmic RNA content, nuclear and nucleolar volume are all significantly reduced in nerve cells of the temporal cortex in cases of Alzheimer's disease, examined both at diagnostic craniotomy and post mortem, when compared with non-demented control cases of similar age. On average, at necropsy, all three parameters are equally reduced by about $40-50 \%$, but in biopsy cases, nuclear volume is decreased by the greatest amount (43\%), followed by nucleolar volume (36\%), and cytoplasmic RNA (26\%). These findings indicate that a change in protein synthesis occurs early in the course of Alzheimer's disease which may result from a primary alteration within the nuclear apparatus.

Recent findings have suggested that disordered protein synthesis in nerve cells may be a feature of Alzheimer's disease. A decrease in RNA/DNA ratio has been measured ${ }^{1}$ in the temporal cortex of patients suffering from Alzheimer's disease which occurs in the absence of any significant change in nerve cells in this area. ${ }^{2}$ In post mortem studies of patients suffering from senile dementia of Alzheimer type substantial losses of nerve cell cytoplasmic RNA content and reductions in nucleolar volume have been reported in many nerve cell types, widespread throughout the CNS. $^{3-5}$ However, the validity of these findings may be questioned since, although factors such as patient age, cause of death and necropsy delay time can be carefully matched in dement and control groups, agonal status and degree of premortem encephalopathy do not readily allow themselves to be accurately estimated. The possible effects of these latter parameters on quantity or dimension of intracellular components cannot be easily judged and, therefore, eliminated from quantitative measurements. These problems are avoided through the use of the cerebral biopsy, where conditions of tissue removal and subsequent treatment can be precisely controlled.

In this report, cytoplasmic RNA content, nuclear and nucleolar volume are measured in

Address for reprint requests: Dr DMA Mann, Department of Neuropathology, The University, Oxford Road, Manchester M13 9PT, UK. Accepted 22 October 1980 nerve cells of the temporal cortex in brain tissue obtained from cases of Alzheimer's disease, at both biopsy and necropsy. Results are compared with those from appropriate control patients.

\section{Materials and methods}

Cerebral biopsies were obtained during diagnostic craniotomy from nine patients (cases 1-9) aged 43 to 66 years (mean, 56 years), with progressive dementia, who presented a syndrome of amnesia, aphasia and visuo-spatial disorder. Eight of the nine patients had evidence of cerebral atrophy on CT scan. Biopsy site was the right (non-dominant) middle temporal gyrus. In addition, biopsy tissue from a similar region of temporal cortex was available from five other cases of similar age range (cases 10-14) undergoing investigation of tumours of the temporal lobe region.

The fresh biopsy tissue was immediately placed in $10 \%$ neutral formalin, fixed overnight and routinely processed. Paraffin sections were cut at $5 \mu \mathrm{m}$ thickness and stained by conventional techniques. Other sections were cut at $16 \mu \mathrm{m}$ thickness and stained with Azure B for measurement of nerve cell cytoplasmic RNA content, nuclear and nucleolar volume. In addition brains were obtained, at necropsy, from five patients who, in life, were clinically diagnosed as suffering from senile dementia of Alzheimer type and ranged in age from 77-85 years (mean, 81 years). Five other cases, ranging in age from 78-85 years (mean, 81 years), who showed no clinical evidence of neurological or psychiatric disorder, were used as controls. There were no significant differences in mean necropsy delay time for both groups and cause of death was 
broadly similar, being associated with cardiovascular or respiratory disease.

Following removal, the brains were suspended in $10 \%$ neutral formalin and from the fixed brain, blocks of tissue were cut from standard areas, including the right middle temporal gyrus, processed and sections cut and stained as above. Measurements of cytoplasmic RNA content and nucleolar volume were made as we have described previously. ${ }^{6} 7$ The maximum diameters of pyramidal nerve cell nuclei were measured and nuclear volume calculated from: $V=$ $\pi / 6 \mathrm{ab}^{2}$, where $a=$ diameter of major axis and $b=$ diameter of minor axis.

\section{Results}

\section{Cytological observations-biopsies}

Neuropathological examination showed numerous senile plaques in layers 1-3 of cortex and nerve cells bearing neurofibrillary tangles, in all layers, with no evidence of vascular disease, in eight of the 14 cases (cases 1-8); these were classed as cases of Alzheimer's disease. The other six cases (cases 9-14) all showed histologically normal cortex and served as "non-Alzheimer control" cases. Examination of the RNA stained sections in the eight cases of Alzheimer's disease showed that the pyramidal nerve cells could be separated into four classes on morphological appearance:

(a) Stage 0. Nerve cells were of a normal appearance with large amounts of cytoplasmic RNA
(Nissl substance) within the cell body and proximal parts of the dendrites. The large, open, nucleus contained finely granular DNA and a strongly positive basophilic nucleolus lying centrally within the nucleus (fig 1a).

(b) Stage 1. Nerve cells show shrinkage of proximal parts of basal and apical dendrites and some reduction in nuclear size. Little obvious loss of cytoplasmic RNA or change in nucleolar volume is seen (fig 1b).

(c) Stage 2. Nerve cells show obvious loss of cytoplasmic RNA, particularly around the nucleus, with the remainder being distributed around the periphery of the cell body. The nucleolus is shrunken and often present, lying against the nuclear membrane, but still retaining strong basophilia. The proximal parts of the dendrites are shrunken and "scraggy" (fig 1c).

(d) Stage 3. Nerve cells show little remaining cytoplasmic RNA and nucleolus (if present) is small and only weakly stained. The nucleus seems unchanged in size from Stage 1, but shows loss of chromatin and evidence of fragmentation of nuclear membrane (fig 1d).

The six non-Alzheimer control cases showed none of these changes within pyramidal cells.

\section{Cytological observations-necropsy cases}

The five cases diagnosed as suffering from senile dementia of Alzheimer type all showed numerous

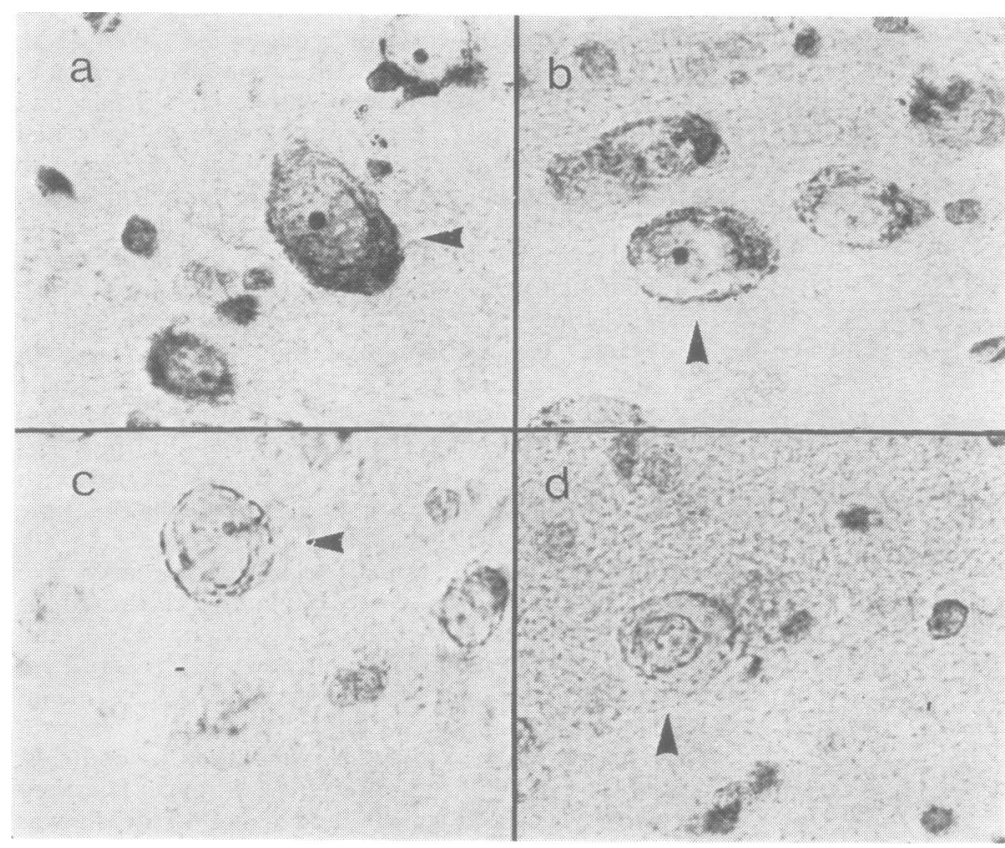

Fig 1 Nerve cells of the temporal cortex in Alzheimer's disease, at biopsy, showing the gradation of changes detailed in the text; la=stage $0 ; 1 b=$ stage $1 ; 1 c=$ stage $2 ; 1 d=$ stage 3 . 
senile plaques and neurofibrillary tangles in all areas of cerebral cortex, hippocampus and amygdala, in the absence of any significant vascular disease or degree of cerebral ischaemic damage. The five aged controls showed minimal degrees of cerebral softening or senile degenerative changes or both, such as occur in such mentally well preserved old persons.

Examination of RNA stained sections of middle temporal cortex, in cases of senile dementia, showed similar changes in the nerve cells as have been described in the biopsy cases, except that fewer cells showing early stages ( 0 and 1$)$ were present, with most cells showing changes typical of stages 2 and 3 .

\section{Cytophotometric results}

For each biopsy case, cytoplasmic RNA content, nuclear and nucleolar volume were estimated on the same cell. For measurement, the nucleolus had to be clearly visible within the section, but otherwise cells were selected at random. As cells were measured they were "labelled" as to which morphological class they belonged (see cytological observations for criteria) until a minimum of 100 pyramidal cells had been measured in both layers 3 and 5 of the cortex.
The mean values of cytoplasmic RNA content, nuclear and nucleolar volume, for all 14 biopsy cases, are shown in table 1 . The mean value of each parameter, in both layers 3 and 5 , in the non-Alzheimer, but demented, control case (case 9) did not differ significantly in $t$ test $(p>0.05)$ from the corresponding mean values obtained from the five non-demented control cases (cases 10-14). Values from these six cases were, therefore, pooled, from which overall mean control values were calculated (table 1). The mean value of each parameter, in cells of both cortical layers, for every case of Alzheimer's disease (cases 1-8) differs significantly in $t$ test $(\mathrm{p}<0.001)$ from the corresponding overall value derived from the six control cases. These values from the eight cases of Alzheimer's disease were also pooled to give overall mean values (table 1) which represent average losses in cytoplasmic RNA, nucleolar volume and nuclear volume of about $25 \%, 34 \%$ and $44 \%$ respectively in pyramidal cells of layers 3 , and $28 \%, 40 \%$ and $42 \%$ respectively in this cell type in layer 5, when compared with the control cases.

If, however, we examine the distribution of values of these three parameters within a single area of any one of the Alzheimer disease cases,

Table 1 Mean values ( $\pm S E$ ) of nuclear volume, nucleolar volume and cytoplasmic RNA content, as measured in pyramidal cells of layers 3 and 5 of temporal cortex, in 8 cases of Alzheimer's disease (1-8) and 6 control cases (9-14), at biopsy. Also shown are overall mean values for Alzheimer and control groups together with mean percentage loss in each parameterfrom the Alzheimer disease cases, when compared with the control values

\begin{tabular}{|c|c|c|c|c|c|c|c|}
\hline \multirow[t]{2}{*}{ Case } & & \multicolumn{2}{|c|}{ Nuclear volume $\left(\mu \mathrm{m}^{3}\right)$} & \multicolumn{2}{|c|}{ Nucleolar volume $\left(\mu m^{3}\right)$} & \multicolumn{2}{|c|}{$\begin{array}{l}\text { Cytoplasmic RNA content } \\
\text { (Arbitrary units) }\end{array}$} \\
\hline & & Layer 3 & Layer 5 & Layer 3 & Layer 5 & Layer 3 & Layer 5 \\
\hline 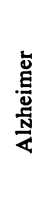 & $\begin{array}{l}1 \\
2 \\
3 \\
4 \\
5 \\
6 \\
7 \\
8\end{array}$ & $\begin{array}{r}920 \cdot 0 \pm 29 \cdot 5 \\
821 \cdot 3 \pm 23 \cdot 0 \\
746 \cdot 8 \pm 22 \cdot 7 \\
941 \cdot 7 \pm 24 \cdot 6 \\
815 \cdot 8 \pm 22 \cdot 6 \\
1115 \cdot 4 \pm 30 \cdot 8 \\
1008 \cdot 6 \pm 22 \cdot 3 \\
1067 \cdot 9 \pm 25 \cdot 7\end{array}$ & $\begin{array}{r}980 \cdot 2 \pm 34 \cdot 8 \\
1182 \cdot 4 \pm 25 \cdot 5 \\
1150 \cdot 4 \pm 31 \cdot 3 \\
941 \cdot 6 \pm 38 \cdot 8 \\
1531 \cdot 3 \pm 37 \cdot 5 \\
1324 \cdot 6 \pm 39 \cdot 6 \\
1111 \cdot 3 \pm 24 \cdot 6 \\
1146 \cdot 2 \pm 45 \cdot 8\end{array}$ & $\begin{array}{r}10.40 \pm 0.22 \\
10 \cdot 86 \pm 0.32 \\
10 \cdot 31 \pm 0.36 \\
11 \cdot 24 \pm 0.36 \\
12.87 \pm 0.39 \\
11 \cdot 12 \pm 0.29 \\
9.82 \pm 0.23 \\
12.04 \pm 0.35\end{array}$ & $\begin{array}{r}10.68 \pm 0.21 \\
9 \cdot 87 \pm 0.19 \\
9 \cdot 75 \pm 0.26 \\
10.98 \pm 0.30 \\
13 \cdot 31 \pm 0.40 \\
10 \cdot 77 \pm 0.31 \\
10.69 \pm 0.30 \\
11 \cdot 53 \pm 0.45\end{array}$ & $\begin{array}{l}27 \cdot 07 \pm 0.82 \\
23 \cdot 89 \pm 0.76 \\
28 \cdot 02 \pm 0.90 \\
28 \cdot 47 \pm 0.92 \\
27 \cdot 99 \pm 0.90 \\
26.42 \pm 0.88 \\
28 \cdot 31 \pm 0.94 \\
27 \cdot 26 \pm 0.77\end{array}$ & $\begin{array}{l}27.25 \pm 0.67 \\
24.74 \pm 0.90 \\
31.09 \pm 0.72 \\
27.62 \pm 0.89 \\
26.98 \pm 0.85 \\
27.54 \pm 0.81 \\
26.68 \pm 0.91 \\
27.62 \pm 0.84\end{array}$ \\
\hline \multicolumn{2}{|c|}{ Mean } & $929 \cdot 7 \pm 45 \cdot 9$ & $1171 \cdot 0 \pm 66 \cdot 4$ & $11 \cdot 08 \pm 0.35$ & $10.95 \pm 0.39$ & $27 \cdot 18 \pm 0 \cdot 53$ & $27 \cdot 44 \pm 0 \cdot 62$ \\
\hline 온 & $\begin{array}{r}9 \\
10 \\
11 \\
12 \\
13 \\
14\end{array}$ & $\begin{array}{l}1666 \cdot 0 \pm 28 \cdot 6 \\
1601 \cdot 9 \pm 24 \cdot 7 \\
1864 \cdot 3 \pm 31 \cdot 2 \\
1506 \cdot 2 \pm 29 \cdot 6 \\
1736 \cdot 8 \pm 34 \cdot 6 \\
1562 \cdot 8 \pm 30 \cdot 3\end{array}$ & $\begin{array}{l}2031 \cdot 3 \pm 40 \cdot 9 \\
1874 \cdot 3 \pm 32 \cdot 6 \\
2461 \cdot 3 \pm 42 \cdot 6 \\
2113 \cdot 4 \pm 41 \cdot 0 \\
1643 \cdot 4 \pm 31 \cdot 8 \\
1996 \cdot 7 \pm 37 \cdot 8\end{array}$ & $\begin{array}{l}15 \cdot 54 \pm 0.23 \\
17 \cdot 57 \pm 0.24 \\
17 \cdot 38 \pm 0.32 \\
16 \cdot 41 \pm 0.38 \\
18 \cdot 02 \pm 0.41 \\
15 \cdot 24 \pm 0.31\end{array}$ & $\begin{array}{l}18 \cdot 43 \pm 0.46 \\
18.63 \pm 0.23 \\
17 \cdot 81 \pm 0.35 \\
19 \cdot 03 \pm 0.37 \\
17 \cdot 14 \pm 0.35 \\
18 \cdot 06 \pm 0.39\end{array}$ & $\begin{array}{l}36 \cdot 03 \pm 0.71 \\
38 \cdot 42 \pm 0.91 \\
36 \cdot 11 \pm 0.83 \\
37 \cdot 02 \pm 0.91 \\
35 \cdot 13 \pm 0 \cdot 80 \\
34 \cdot 61 \pm 0.91\end{array}$ & $\begin{array}{l}38.28 \pm 0.85 \\
39 \cdot 23 \pm 0.90 \\
37.04 \pm 0.90 \\
37.77 \pm 0.86 \\
36.04 \pm 0.91 \\
39 \cdot 16 \pm 0.93\end{array}$ \\
\hline \multicolumn{2}{|c|}{ Mean } & $1656 \cdot 3 \pm 52 \cdot 9$ & $2020 \cdot 1 \pm 110 \cdot 6$ & $16 \cdot 69 \pm 0 \cdot 47$ & $18 \cdot 18 \pm 0 \cdot 27$ & $36 \cdot 22 \pm 0.56$ & $37 \cdot 92 \pm 0.51$ \\
\hline \multicolumn{2}{|c|}{$\begin{array}{l}\text { Mean } \% \text { loss } \\
\text { from Alzheimer } \\
\text { cases }\end{array}$} & $43 \cdot 9 *$ & $42 \cdot 0^{*}$ & $33 \cdot 6^{*}$ & $39 \cdot 8 *$ & $25 \cdot 0^{*}$ & $27 \cdot 6^{*}$ \\
\hline
\end{tabular}

*Statistically significant $(t$ test); p $<0.001$. 
then a clearer picture of the changes emerges. Cytoplasmic RNA content, nuclear and nucleolar volume were measured, as a typical example, in 100 pyramidal cells of layers 5 , in case 1 , with 25 falling into each of the four morphological classes outlined above. The mean value of each parameter was determined for each morphological class. These latter mean values were then expressed as percentage of the corresponding value previously estimated in the six non-Alzheimer "control" cases (cases 9-14) (table 1) and these percentage values are shown for each parameter, at each stage, in fig 2 .
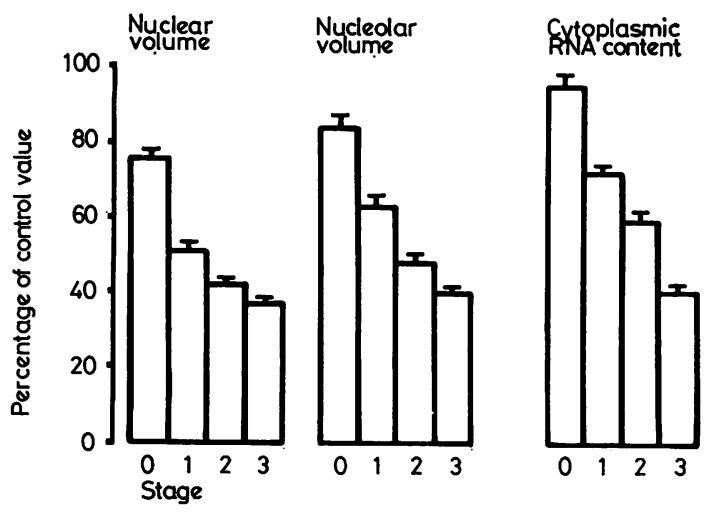

Fig 2 Histogram showing values of mean $(+S E)$ nuclear and nucleolar volume and cytoplasmic $R N A$ content, of nerve cells of temporal cortex at biopsy, expressed as percentage of control values, classed into stages 0 to 3, according to the morphological criteria detailed in text and shown in fig 1.

Figure 2 shows that even those cells classed on morphological appearance as normal (Stage 0) show reductions of about $25 \%$ in nuclear volume, $16 \%$ in nucleolar volume and $5 \%$ in RNA content; changes of such magnitude are not likely to be discerned by visual appraisal. The percentage values of each parameter are progressively reduced through each morphological class, such that, by stage 3 , each value is similarly reduced by about $60 \%$. However, at both stages 1 and 2 , it is noticeable that nuclear volume is always reduced by the greatest amount, followed by nucleolar voume and RNA content.

These results clearly demonstrate that, although on average all three parameters are significantly reduced in amount ranging from $25 \%$ to $44 \%$, the greatest and indeed earliest involvement is with nuclear volume, followed both in event and magnitude by nucleolar volume and finally RNA content. These findings in the biopsy cases are broadly matched by results of similar studies in the necropsy cases (table 2). Here, mean cytoplasmic RNA content, nuclear and nucleolar volume are, again, all significantly reduced $(p<0.001)$ in both layers 3 and 5 of temporal cortex, in the group of patients suffering from senile dementia of Alzheimer type, when compared with appropriate values from the aged control group. However, in this instance all three parameters are similarly reduced by about $40-50 \%$ in both cases.

\section{Discussion}

When taken overall, values of cytoplasmic RNA content, nucleolar and nuclear volume of pyramidal cells of layers 3 and 5 of the temporal cortex in cases of Alzheimer's disease, examined at biopsy, show significant losses in nuclear volume of $43 \%$, nucleolar volume $36 \%$ and cytoplasmic RNA $26 \%$, when compared with values from appropriate control cases of similar age. These results not only demonstrate an early alteration in protein synthesis capability in nerve cells but also indicate that the findings in other brain regions at necropsy, reported elsewhere by us, ${ }^{3-5}$

Table 2 Mean values of cytoplasmic RNA content, nucleolar and nuclear volume, as measured in pyramidal cells of layers 3 and 5 of temporal cortex in 5 cases of senile dementia of Alzheimer type and 5 control cases of similar age, all at necropsy

\begin{tabular}{|c|c|c|c|c|c|c|}
\hline & \multicolumn{2}{|c|}{ Layer 3 pyramids } & \multirow{2}{*}{$\begin{array}{l}\% \\
\text { loss }\end{array}$} & \multicolumn{2}{|c|}{ Layer 5 pyramids } & \multirow{2}{*}{$\begin{array}{l}\% \\
\text { loss }\end{array}$} \\
\hline & Senile dement & Senile control & & Senile dement & Senile control & \\
\hline $\begin{array}{l}\text { Cytoplasmic } \\
\text { RNA content }\end{array}$ & $\begin{array}{c}15 \cdot 22 \pm \\
1 \cdot 12\end{array}$ & $\begin{array}{c}29 \cdot 34 \pm \\
1.53\end{array}$ & $48 \cdot 12^{*}$ & $\begin{array}{r}14 \cdot 37 \\
1 \cdot 22\end{array}$ & $\begin{array}{r}31 \cdot 26 \\
1 \cdot 68\end{array}$ & $54 \cdot 03^{*}$ \\
\hline $\begin{array}{l}\text { Nucleolar } \\
\text { volume }\end{array}$ & $\begin{array}{l}7.02 \pm \\
0.53\end{array}$ & $\begin{array}{c}12 \cdot 60 \pm \\
0 \cdot 74\end{array}$ & $44 \cdot 29 *$ & $\begin{array}{l}8 \cdot 21 \pm \\
0.52\end{array}$ & $\begin{array}{c}14.51 \pm \\
0.76\end{array}$ & $43 \cdot 69 *$ \\
\hline
\end{tabular}

*Statistically significant ( $t$ distribution) $\mathrm{p}<0.001$. 
are unlikely to arise from factors related to mode of death or post mortem artefact. Furthermore, this present study of biopsy cases has shown that the manner and extent of involvement of these three parameters in the disease process is not equivalent. Initially, nuclear volume is reduced greatly, while nucleolar volume and RNA content are less changed respectively. As the degenerative process progresses, then all three parameters are further decreased, but again in this same order, until eventually all are equally reduced.

In the necropsy cases, however, all three parameters were found to be equally reduced by 40 $50 \%$. These greater reductions may be due to more pronounced effects of the illness in this latter group.

Although the extent of dementia was fully measured in the biopsy group of patients (Nearyunpublished observations) and substantial deficits in choline acetyl transferase activity were noted in the biopsy tissue also, ${ }^{8}$ parallel psychometric measurements and biochemical assays could not be made on the necropsy group of patients. However, as described here under cytological observations, early changes in nuclear and cytoplasmic morphology were noted in only a few cells, at necropsy, with most showing those changes characteristic of later stages in the disease process. Furthermore, the overall frequency of both senile plaques and nerve cells bearing neurofibrillary tangles (table 3 ) was significantly greater in the necropsy group $(p<0 \cdot 01)$. Both these latter findings, therefore, despite the absence of confirmatory psychometric and biochemical measures, imply a more advanced disease process in the autopsy group. This may be due to the slightly longer duration of illness in this group per se (mean 5.6 years, compared with 3.9 in the biopsy group ( $<<0.051$ tail test) with three under two years (table 3 ), or it may be the disease process also manifests itself more severely in the less physically able elderly.

Thus the results of this study suggest that the initial site of action of the pathogen lies within the nucleus, with the later changes in nucleolar volume and cytoplasmic RNA content presumably following as a secondary consequence to alterations in RNA synthesis within the nucleus, through interference with transcriptive or translative processes.

Crapper and colleagues, ${ }^{9}$ using a bacterial polymerase probe, have shown that, of the total DNA content of nerve cells, only the euchromatin and light chromatin fractions are capable of RNA synthesis with the heterochromatin fraction being completely inactive in this respect. The euchromatin and light chromatin fractions account for $75 \%$ of total DNA in elderly indviduals without evidence of dementia, but this is reduced in cases of Alzheimer's disease to $55 \%$ of total DNA. This increase in heterochromatin could not be explained in terms of non-specific factors such as patient age, terminal illness, variation in post mortem delay time, duration of tissue storage while frozen. Furthermore, the neurone enriched fraction, on which these measurements were made, showed, in Alzheimer's disease, a reduced proportion of nuclei with diameter greater than $12 \mu \mathrm{m}$ (about $1000 \mu \mathrm{m}^{3}$ in volume) and an increase in those less than $6 \mu \mathrm{m}$ in diameter, which were

Table 3 Details of age, duration of symptoms of dementia, frequency of senile plaques and nerve cells bearing neurofibrillary tangles, for 13 cases of Alzheimer's disease, 8 examined at biopsy, 5 at necropsy. Overall mean values $( \pm S E)$ are given for each group

\begin{tabular}{|c|c|c|c|c|c|c|c|c|c|}
\hline \multicolumn{5}{|l|}{ Biopsy } & \multicolumn{5}{|c|}{ Necropsy } \\
\hline \multirow[t]{2}{*}{ Case } & \multirow{2}{*}{$\begin{array}{l}\text { Age } \\
\text { (years) }\end{array}$} & \multirow{2}{*}{$\begin{array}{l}\text { Duration of } \\
\text { symptoms } \\
\text { (vears) }\end{array}$} & \multicolumn{2}{|c|}{ Frequency* } & \multirow[t]{2}{*}{$\overline{\text { Case }}$} & \multirow{2}{*}{$\begin{array}{l}\text { Age } \\
\text { (years) }\end{array}$} & \multirow{2}{*}{$\begin{array}{l}\text { Duration of } \\
\text { symptoms } \\
\text { (years) }\end{array}$} & \multicolumn{2}{|c|}{ Frequency* } \\
\hline & & & $\begin{array}{l}\text { Senile } \\
\text { plaques }\end{array}$ & $\begin{array}{l}\text { Neurofibrillary } \\
\text { tangles }\end{array}$ & & & & $\begin{array}{l}\text { Senile } \\
\text { plaques }\end{array}$ & $\begin{array}{l}\text { Neurofibrillary } \\
\text { tangles }\end{array}$ \\
\hline $\begin{array}{l}1 \\
2 \\
3 \\
4 \\
5 \\
6 \\
7 \\
8\end{array}$ & $\begin{array}{l}66 \\
56 \\
55 \\
53 \\
55 \\
57 \\
60 \\
59\end{array}$ & $\begin{array}{l}6 \\
5 \\
1 \\
1 \\
2 \\
4 \\
5 \\
7\end{array}$ & $\begin{array}{r}2.6 \\
51.4 \\
16.4 \\
34.4 \\
21 \cdot 1 \\
38.6 \\
20.5 \\
27.6\end{array}$ & $\begin{array}{r}3 \cdot 1 \\
38 \cdot 4 \\
14 \cdot 7 \\
19 \cdot 6 \\
30 \cdot 0 \\
31 \cdot 2 \\
23 \cdot 2 \\
28 \cdot 1\end{array}$ & $\begin{array}{l}1 \\
2 \\
3 \\
4 \\
5\end{array}$ & $\begin{array}{l}77 \\
79 \\
82 \\
82 \\
85\end{array}$ & $\begin{array}{l}4 \\
5 \\
5 \\
8 \\
6\end{array}$ & $\begin{array}{l}40 \cdot 4 \\
52.6 \\
62.6 \\
66 \cdot 8 \\
75 \cdot 4\end{array}$ & $\begin{array}{l}35 \cdot 4 \\
48 \cdot 4 \\
48 \cdot 7 \\
51 \cdot 4 \\
60 \cdot 2\end{array}$ \\
\hline Mean & $\begin{array}{c}57 \cdot 6 \pm \\
1 \cdot 4\end{array}$ & $3.9 \pm 0.8 \dagger$ & $\begin{array}{l}26 \cdot 6 \pm t \\
5 \cdot 3\end{array}$ & $\begin{array}{c}23 \cdot 5 \pm \ddagger \\
3 \cdot 9\end{array}$ & Mean & $\begin{array}{c}81 \cdot 0 \pm \\
1 \cdot 4\end{array}$ & $5 \cdot 6 \pm 0 \cdot 7$ & $\begin{array}{c}59.6 \pm \\
6.0\end{array}$ & $\begin{array}{c}48 \cdot 8 \pm \\
4 \cdot 0\end{array}$ \\
\hline
\end{tabular}

* Number per mm²

$\dagger,+$ Significantly different from autopsy group.

$\mathrm{p}<0.05$ (1 tail), $<0.01$ (2 tail) respectively. 
not due to glial contamination. These findings are in keeping with our results, in that reduction in nuclear volume is accompanied by heterochromatisation of DNA resulting in diminished RNA synthesis. These authors have also shown that, by analysis of RNA chain length, the products of RNA synthesis formed by the Alzheimer's disease tissue do not significantly differ in length distribution from those produced by control tissue. Such an observation favours a deficit by transcriptically active DNA being reduced without alteration in its genetic makeup.

The increased appearance of intranuclear rodlets, perichromatin granules and other inclusions in nerve cells of cases of Alzheimer's disease $^{10}$ may be of significance in this process of heterochromatisation and nuclear shrinkage.

The nuclear alterations reported here and elsewhere $^{910}$ could be due to a direct effect of the pathogenic agent upon the genetic apparatus, but it is also possible that they simply represent reduced demands for protein output stemming from synaptic deficiencies ${ }^{1581112}$ which result in a decreased throughput of action potentials. This question cannot be resolved until a thorough examination of factors regulating gene expression, particularly hormones, are examined.

We thank Mrs P Bellinger for the preparation of the manuscript.

\section{References}

1 Bowen DM, Smith CB, White P, Flack RHA, Carrasco LH, Gedye JL, Davison AN. Chemical pathology of the organic dementias. Brain 1977; 100:427-53.
2 Terry RD, Fitzgerald C, Peck A, Millner J, Farmer P. Cortical cell counts in senile dementia. J Neuropath Exp Neurol 1977; 36:633.

3 Mann DMA, Yates PO, Barton CM. Cytophotometric mapping of neuronal changes in senile dementia. J Neurol Neurosurg Psychiatry 1977; 40:299-302.

4 Mann DMA, Sinclair KGA. The quantitative assessment of lipofuscin pigment, cytoplasmic RNA and nucleolar volume in senile dementia. Neuropath Appl Neurobiol 1978; 4:129-35.

5 Mann DMA, Lincoln J, Yates PO, Stamp JE, Toper S. Changes in monoamine containing neurones of the human CNS in senile dementia. Br J Psychiatry 1980; 136:533-41.

6 Mann DMA, Yates PO. Lipoprotein pigments: their relationship to ageing in the human nervous system. Brain 1974; 97:481-8.

7 Mann DMA, Yates PO, Stamp JE. Relationship of lipofuscin pigment to ageing in the human nervous system. J Neurol Sci 1978; 35:83-93.

8 Sims NR, Bowen DM, Smith CCT, Flack RHA, Davison AN, Snowden JS, Neary D. Glucose metabolism and acetylcholine synthesis in relation to neuronal activity in Alzheimer's disease. Lancet I, 1980; 1:333-6.

9 Crapper DR, Quittkat S, De Boni U. Altered chromatin conformation in Alzheimer's disease. Brain 1979; 102:483-95.

10 Toper S, Bannister CM, Lincoln J, Mann DMA, Yates PO. Nuclear inclusion bodies in Alzheimer's disease. Neuropath Appl Neurobiol 1980; in press.

11 Perry EK, Gibson PH, Blessed G, Perry RH, Tomlinson BE. Neurotransmitter enzyme abnormalities in senile dementia. J Neurol Sci 1977; 34:247-65.

12 Davies P. Neurotransmitter related enzymes in senile dementia of the Alzheimer type. Brain Res 1979; 171:319-27. 